\title{
Cultural Differences in English Literature for Chinese Students
}

\author{
Dini Zhang \\ English Department, Literature and Law School of Sichuan Agricultural University, Ya'an, Sichuan Province, China \\ Email: Zhangdini0000@126.com \\ Huaiyong Gao \\ English Department, Literature and Law School of Sichuan Agricultural University, Ya'an, Sichuan Province, China \\ Email: cliff625@126.com
}

\begin{abstract}
Generally, Chinese students, majoring in English literature, have their difficulties in study. The main problem is that they could not understand the works well. Concerning some primary aspects of culture which are reflected in English literature, from the point of intercultural communication, they are advised to learn more knowledge of the English culture as well as their study in English literature.
\end{abstract}

Index Terms-intercultural communication, cultural differences, English literature, Chinese student

With the rapid development of communications, the earth has become a village. The arrival of globalization accelerates the communications among all countries. It also accelerates the intercultural communication. In this trend, the culture plays an important role. For a long time, Chinese students, majoring in English literature, have some problems in their studies. Sometimes, they could not appreciate English works well, even with anxiety in their studies. How do those problems arise? This is not the fault of their abilities, for they are lack of the relative knowledge of the English culture. In order to do a good job in English literature, they need to study the relative knowledge of English culture at different period as well as their studies in English literature.

Of culture, different people hold different opinions. In OED, the culture is defined as "the training development, and refinement of mind, tastes, and manners; the condition of being thus trained and refined; the intellectual side of civilization" $(4 \mathrm{vol}$, p. 121). This definition is abstract. In order to support the purpose of this article, the definition of culture of Bates and Plog is citied here:

Culture is a system of shared beliefs, values, customs, behaviors, and artifacts that the members of a society use to cope with their world and with one another, and that are transmitted from generation to generation through learning. This definition includes not only patterns of behavior but also patterns of thought (shared meanings that the members of a society attach to various phenomena, natural and intellectual, including religion and ideologies), artifacts (tools, pottery, houses, machines, works of art), and the culturally transmitted skills and techniques used to make the artifacts. (qtd. in Samovar et al., 1998, p. 36)

So the culture covers beliefs, values, customs, behaviors, and artifacts of a society. Literature, defined in OED as "the body of writings produced in a particular country or period", reflects beliefs, customs of a society of certain period (15vols, p. 294). It is inseparable from the culture. As Fred Whitehead (1994) has said in his book, Culture Wars: "Without literature [...] the fine art of comparison is lost" (p. 19). He emphasizes in his book that the literature plays an important role in culture wars in America. He thinks that the literature can give moral instruction to the young people. That is to say, the culture has literature in it, and the literature is a mirror of culture. In The 7th Triennial Conference of Chinese Comparative Literature Association and the International Conference, Douwe W. Fokkema, Professor of Utrecht University, Netherlands, President Emeritus of ICLA, gives his speech, "Is There a Specific Role for Literature Reading in Cultural and Cross-Cultural Communication?", and recalls all that the literature is very important in cultural and intercultural communication (Chen, Aimin and Lixin Yang, 2003, p. 11-23). It is no doubt that literature is very important to culture.

In English literature learning, there are four important aspects concerning English culture, namely, language, Christianity, traditional cosmology and Greek myths, and customs. They do much help in studying the English literature.

First of all, it is the language. Language plays an important role in a culture. It is also true for English culture.

Why the language is so important in a culture? Because it is the way human being making contact with the surroundings. It is a set of words and rules understood by a large group of people. With language, one can exchange his ideas with others, finish an action, record down his thought, and learn information from outside world, etc., even with the people from different countries. It is impossible to separate language from culture. It is the vehicle of the culture.

To learn English literature, the first step is to learn English well. As a language, English shows the thought patterns of English people. For Chinese, they have thought patterns of Chinese, and English has their thought patterns. Only one learns the language, he can understand what he is reading, or studying. Then he can communicate with the writer, or 
others. Based on understanding, one can make progress in understanding English culture. So the ability of language is the first step in communication. In English literature, to learn English well is very important. If one does not learn English, how can he understand the texts of English literature, then English culture?

To learn language is the first step, and then one must know more about language, such as the hierarchies of language, and usage of words, etc.

As Eugene A Nida (1993) has pointed out in his book, Language, Culture, and Translating: "A language does reflect in certain aspects the culture of a society, but primarily in its optional features. i.e. in certain of its hierarchies of vocabulary and in the priorities given to various discourse patterns" (p. 107). "The hierarchies of vocabulary, that is, the ways in which terms representing classes of entities, activities, and characteristics are built up into taxonomies (both popular and scientific), reflect in a large measure the manner in which people understand and classify the world in which they live" (p. 108). The hierarchies of language are very common in every language, so does in English. When talking about the same thing, people of different classes use different words. And the words show their classes. In Great Expectations, one of Dickens' novels (1965), Pip was jeered by Estella, when he called the jacks the knaves in playing cards with her (ch. 8). Pip was a boy from working class, whose brother-in-law was a smith, and Estella was a girl reared by Miss. Havisham, a lady. The different usages of words show their class differences.

As Nida (1993) pointed out: "the knowledge of certain terms is often an index to competence in a particular field of endeavor, and the disappearance of terms from the vocabulary of a large segment of a society may indicate a significant change in the concerns of a culture" (p. 109). Some words used in poems, called archaism, are seldom in use today, such as ay, thou, thy, doest, etc. They are always, you, your, do in today's meanings. And if one carefully studies the literary works before and after 17th century, he is surely to find some difference in the works before the end of 17th century and after 17th century. The word it seldom appears in the works before 17th century. In Milton's Paradise Lost, there are only several it. But in 18th century, the word it is popularly used.

In his book A Linguistic Guide to English Poetry, Geoffrey N. Leech (2001) distinguishes poetic language from "ordinary" language (p. 5). In simple words, the poets use special words to refer the ordinary things. Examples are prime, the eye of heaven, bark, lea, and deep, etc. These are periphrases for "spring", "sun", "boat", "meadow", and "sea" in the poems respectively.

Ms. Liu Yiqing, Professor of Peking University, has mentioned in her class that special attention should be paid to the pronoun in reading the novels of 18th century. Sometimes, there are several he in one sentence, but they refers to different people. If one cannot make a clear distinction, he is surely to get confusion.

From the above four points, it shows the important position of language in English culture and English literature study. So in studying English literature, learning English language well is the first step. If one cannot master English and understand the works, how can he talk about the English literature? With more knowledge about language, that is to say, his abilities in language, he actually understands the work itself and has a better understanding of the author.

Second, it is the religion should be given much attention. Concerning religion, Christianity is the major one mentioned here. It plays an important role in the life of English people.

Christianity has a long history. From the beginning to present day, it has passed more than one thousand years. During the long history, it has developed many branches, such as Catholic, Protestant, Pietist, Huguenot, Presbyterian, Latitudinarian, Methodist, Mennonite, Congregationalist, Quarker, Baptist, Unitarian, etc. (Gay, 1996, p. 36). As a Western country, England is also influenced by Christianity. Tracing the English history, it is easy to find many historical events about Christianity. One most important example is the Henry VIII. In order to divorce his first wife, Catherine of Aragon, he broke from the Catholic Church by the Act of Supremacy. This is a great event in English history. It is the founding of Anglican Church. Nowadays, religion also has an important place in social life of England. In 1943 the UK government published the White Paper. It preceded the 1944 Education Act. Board of Education considers the essential goal of religious education is to concern for traditional and religious values in the daily life:

There has been a general wish not confined to representatives of the churches, that religious education should be given a definite place in the life and work of schools, springing from the desire to revive the spiritual and personal values in our society and in our national tradition. (qtd. in Cairns, 2001, p. 61)

It is clear that the religion is an important part in English culture.

As the religion provides people values, philosophies of life, and moral criteria, Christianity also gives them to the English people. So, most writers are believers, belong to this or that branches of Christianity. In the works of those writers, they always choose religious themes, such as religious poems of John Donne and the Metaphysical poets. In 17th century, there are two important works. One is John Milton's Paradise Lost; another is John Bunyan's The Pilgrim's Progress. As Christianity, Milton chose the story of the fall of Adam to write his epic. When he thought he should write something immortal, he considered only the story from the Bible could serve his purpose. So he produced his masterpiece Paradise Lost. John Bunyan is another important writer of the 17th century. He is a tinker, and a persecuted Dissenter. His reading of the Bible in prison, combined with his spiritual experience, gave him sensitive imagination with great impressions and vivid images. He wrote them down and came The Pilgrim's Progress. This book is a religious allegory. It tells people what is virtue and what is vice. No one would think it is a truth story, but everyone would think it is a wonderful literary work.

In 18th century, the novel flourished. Many novels served the function of moral preach. Many novelists used names 
and stories from the Bible to serve this function. Take The History of the Adventures of Joseph Andrews, and of His Friend Mr. Abraham Adams: Written in Imitation of the Manner of Cervantes, Author of Don Quixote of Henry Fielding as an example. Packed out of his mistress' house, Joseph sets out to find his sweetheart Fanny. With a friend meeting on the road, Parson Adams, he encounters many adventures, and reunions with his lover at last. In Bible, Joseph is the name of the son of Jacob. He is betrayed by his brother and sold to Egypt. In the novel, Joseph has similar experience. $\mathrm{He}$ is robbed and beaten by the outlaws. It is not a coincidence. Fielding used the allegory in Bible to enhance the moral theme in the novel. The parson, Abraham Adams, as the title of the novel indicates, is an English Don Quixote. He is a special role in the novel. His name bears special meanings. Abraham is the tribe leader of Jews. He symbols the father of the tribe. Here, the name means the parson is like a father who will accompany Joseph to go from vice London to the virgin country. And also, Fielding gave the priest the name Adams. Adams contains "Adam", who is the grandfather of human being. This name indicates the simple and good personality of the parson, and enhances his parental position in this novel.

From the above examples, it shows that religion occupies the important position in English literature.

The third aspect is about the cosmology and Greek myths. The Western culture is greatly influenced by the cosmology and myths of ancient Greece. Though Christianity dominates the western countries for more than one thousand years, but the Europeans still reserved many traditional thoughts of ancient Greece. The cosmology and myths are two important fields. During Renaissance, it is the rediscovering of the ancient civilization. Many writers used many ancient terms and knowledge to express their ideas.

Here is an example from Chaucer's The Canterbury Tales:

When the sweet showers of April fall and shoot

Down through the drought of March to pierce the root,

Bathing every vein in liquid power

From which there springs the engendering of the flower,

When also Zephyrus with his sweet breath

Exhales an air in every grove and hearth

Upon the tender shoots, and the young sun

His half-course in the sign of the Ram has run,

And the small fowls are making melody

That sleep away the night with open eye [. . . (The Prologue 1-10)

The first line indicates that the story happens in April. But it does not say on which day. With the knowledge of cosmology, one can find a cue from the poem. It is the sentence, "the young sun / His half-course in the sign of the Ram has run", that gives the clue. There is something about zodiac. In western tradition, the zodiac belt is a very important concept of cosmology. There is a belt of celestial sphere, which is divided into twelve parts, named after twelve constellations, Aries, Taurus, Gemini, Cancer, Leo, Virgo, Libra, Scorpio, Sagittarius, Capricorn, Aquarius, and Pisces. These symbols are Ram, Bull, Twins, Crab, Lion, Virgin, Scales, Scorpion, Archer, Goat, Water-bearer, and Fishes. Each of them represents a month. The sun passes through in each month. And the sun is supposed to enter the Ram later in March and to leave it beyond the middle of April. So in the poem, the time is near the eleventh of April. It is just like the lunar calendar of China.

In those lines, there is another word to mention, Zephyrus. It is a name of Greek God, here representing the west wind. It takes the winter away, and brings the spring.

In 17th century, the Metaphysical poet, John Donne, wrote many religious poems. But he also used some concepts of cosmology in his poems. His poem, A Valediction: Forbidding Mourning, describes his departure from his wife:

Moving of th' earth brings harms and fears,

Men reckon what it did and meant,

But trepidation of the spheres,

Though greater far, is innocent. (9-12)

Here, the "trepidation of the spheres" means the moving of the planets. According to he Ptolemaic system, the universe is round. Earth is the center of the universe. Outside of the earth, there are nine degrees of sphere. From earth, they are Moon, Mercury, Venus, Sun, Mars, Jupiter, Saturn, Fixed Star, and Crystal sphere. The Crystal sphere is the prime mobile of the sphere. Its motion causes the moving of the other planets. The moving of the planets is far greater than the moving of the earth, earthquake. But it does not do harm to man like the earthquake. The poet used this metaphor to mean that the departure of secular lovers is like the earthquake, which causes terror and sorrow, and the departure of spiritual lovers is like the moving of planets, which produce tranquility and harmony. With this metaphor, the poet gave the readers more vivid impression.

Greek myths are another source of English literature. Like Zephyrus appears in Chaucer's The Canterbury Tales, many writers used names of Greek gods in their works, such as Apollo, Daphne, Pan, and Syrinx in a poem of Donne, The Garden. In Greek myth, there is a story of Prometheus. As punishment, Zeus deprived humankind of fire. In order to give human being a better life, Prometheus climbed to the heavens, got a sparkle from the chariot of the sun, and taught man how to use fire. In retribution for this action, Zeus chained Prometheus to a rock on Mount Caucasus, and spread evils over the world through Pandora's box. This story has some resonance: the courage needed to disobey the 
gods, the "fire" of intelligence. Prometheus became the symbol of noble-hearted revolutionaries. Continued with this story, Percy Bysshe Shelley wrote his masterpiece, Prometheus Unbound. He created a figure of moral perfection, which is liberated by benign forces in the universe and triumphs over Tyranny. So with the Greek background, one can understand this lyrical drama better.

And last, customs are also important in English culture. Below is the excerpt from Christopher Marlowe's poem, The Passionate Shepherd to His Love:

The shepherd swains shall dance and sing,

For thy delight, each May morning.

If these delights thy mind may move,

Then live with me, and be my love. (25-28)

In this poem, everyone can understand what poet wants to say. But one will miss the meaning of "May". In general, most people would consider it means the time of the shepherd pursues his lover. But why it must be in May? In England, May Day is a traditional festival. On that day, the young lovers wear garlands and dance around a Maypole, painted with spiral stripes and decked with flowers, to show their love. One girl will be chosen as the queen of the May, who is gaily dressed and crowned with flowers. It is the happiest of the young people in a year. Though May Day has become an international Labour holiday, but it is still a national festival for young people in England. The poet used this image to indicate his love to his lover. So, with the background of customs, the poet is understood better.

From what has been discussed above, it is clear that, in studying English literature, the Chinese students should pay more attention to these important aspects, language, religion, cosmology and Greek myths, and customs, etc. These are the principle elements concerning the English culture. To learn more about English culture, it will help Chinese students to understand English literature and communicate easily with English people.

\section{REFERENCES}

[1] Bunyan, John. (1969). The pilgrim's progress. New York: Airmont Publishing Company, Inc.

[2] Cairns, Jo, Denis Lawton and Roy Gardner. (2001). Values, culture and education. London: Kogan Page.

[3] Chaucer, Geoffrey. (1951). The Canterbury tales. Middlesex, England: Penguin Books Ltd.

[4] Chen, Aimin, and Lixin Yang (eds.) (2003). Comparative literature in the cross-cultural context. Nanjing: Yilin Press.

[5] Dickens, Charles. (1965). Great expectations. Middlesex, England: Penguin Books Ltd.

[6] Donne, John. (1971). The complete English poems. A. J. Smith (ed.). Harmondsworth, Middlesex, England: Viking Penguin Inc.

[7] Fielding, Henry. (1987). Joseph Andrews. Basingstoke, Hampshire: Macmillan.

[8] Gay, Peter. (1966). The age of Enlightenment. New York: Time-Life International (Nederland) B. V.

[9] Leech, Geoffrey N. (2001). A linguistic guide to English poetry. Beijing: Foreign Language Teaching and Research Press.

[10] Milton, John. (1975). Paradise lost: An authoritative text backgrounds and sources criticism. Scott Elledge (ed.). New York: Norton.

[11] Nida, Eugene A. (1993). Language, culture, and translating. Shanghai: Shanghai Foreign Language Education Press.

[12] The Oxford English Dictionary. (1989). (2 $2^{\text {nd }}$ edn.) (20 vols.). Oxford: Clarendon Press.

[13] Samovar, Larry A., Richard E. Porter, and Lisa A. Stefani. (1998). Communication between cultures. Belmont, CA: Wadsworth Publishing Company.

[14] Whitehead, Fred. (1994). Culture wars: opposing viewpoints. San Diago, CA: Greenhaven Press Inc.

Dini Zhang was born in Huaiyang, Henan Province, China in 1982. She received her M. A. degree in literature from Hunan University, China in 2008.

She is currently a lecturer in English Department of Literature and Law School, Sichuan Agricultural University, China. Her research interests include English literature and American literature.

Huaiyong Gao was born in Ya'an, Sichuan Province, China in 1974. He received his M. A. degree in literature from Southwest Jiaotong University, China in 2008.

He is currently an assistant professor in English Department of Literature and Law School, Sichuan Agricultural University, China. His research interests include applied linguistics and English literature. 